Інноватика у вихованні. Випуск 11. Том 1. 2020.

УДК 378.018.8:373.5.011.3-051:[94+34]:340.1

DOI: $10.35619 /$ iiu.v1i11.255

Коваль Дар'я

здобувачка Уманського державного педагогічного університету імені Павла Тичини,

м. Умань, Україна

ORCID: 0000-0003-0765-7649

e-mail:akoval85@gmail.com

\title{
ПЕДАГОГІЧНІ УМОВИ ФОРМУВАННЯ ПРАВОВОЇ КУЛЬТУРИ МАЙБУТНІХ УЧИТЕЛІВ ІСТОРІЇ ТА ПРАВОЗНАВСТВА У ФАХОВІЙ ПІДГОТОВЦІ
}

\begin{abstract}
Анотація. У статті розкрито сутність поняття «педагогічні умови», яке може бути представлене крізь призму таких підходів: 1) комплекс заходів, зміст, методи i форми виховання, що забезпечують організацію матеріально-просторового середовища; 2) елемент педагогічної системи, що відображає можливості освітнього середовища та впливу на студентів (зміст, засоби, форми, технології). Педагогічні умови визначено як сукупність організаційних форм, педагогічних взаємодій, змісту навчання (дисциплін), що здійснюють цілеспрямований вплив на студентів у ході їх фахової підготовки.

3'ясовано, що необхідними педагогічними умовами $є$ ті, які забезпечують процес формування правової культури майбутніх учителів у ході фахової підготовки, а під достатніми - таке їх поєднання, яке забезпечує ефективність цього процесу.
\end{abstract}

Обгрунтовано педагогічні умови формування правової культури майбутніх учителів історії та правознавства у фаховій підготовці, а саме: стимулювання мотивації пізнавальної діяльності, ціннісного ставлення студентів до норм права 3 урахуванням сучасних суспільно-історичних реалій з використанням інноваційних форм і активних методів навчання; диверсифікація змісту навчальних дисциплін для формування у студентів позитивного ставлення до правових знань; використання освітніх технологій, що забезпечують реалізацію правового досвіду (педагогічна і правова практики, правовиховна діяльність, громадська активність).

Розкрито процес реалізації першої педагогічної умови, що здійснювався в ході застосування інноваційних форм та активних методів навчання; другої - через вивчення студентами навчальних дисциплін та спецсемінарів; третьої - за допомогою освітніх технологій.

Ключові слова: педагогічні умови, формування правової культури, майбутні учителі історії та правознавства, норми права, фахова підготовка, правовиховна діяльність.

Постановка проблеми. Стан правової культури будь-якої держави є важливим показником зрілості конкретно-історичної правової системи. Історичний розвиток кожної країни і народу знаходить своє відображення у рівнях сформованої правової культури. Позитивні зміни в сучасній освіті зумовлюють необхідність нового підходу до осмислення правової культури та активізації теоретичних досліджень у ії галузі. Пріоритетна роль у цьому належить вищій школі, яка покликана забезпечити відтворен ня і розвиток правової культури як складної системи загальнолюдських цінностей, технологій і творчості.

(C) Коваль Д., 2020 
Удосконалення процесу формування правової культури майбутніх учителів, зокрема історії та правознавства, потребувало розробки педагогічних умов забезпечення цього процесу.

Аналіз останніх досліджень 3 проблеми. Умови, на відміну від більш широкого поняття «причини», в теорії і практиці розглядаються як щось зовнішнє для явища, Умови, які не є причиною подій, у той же час підсилюють або послаблюють дію причини. 3 таких позицій Л. Ніколаєва визначає умови як чинники, обставини, від яких залежить ефективність функціонування педагогічної системи (Николаева, 2005, с.79).

У філософії поняття «умова» визначається як ставлення предмета до навколишніх явищ, без яких він існувати не може (Шахбанова, 2012, с.60), як сукупність об'єктів (речей, процесів, які стосуються використання), необхідних для виникнення, існування або зміни будь-якого об'єкта (Даудов, 2017, с.60).

На думку А. Шайдурова, умови - це сукупність факторів, компонентів навчального процесу, що забезпечують успішність навчання (Шайдурова, 2001, c. 128).

Визначити умови як складовий елемент педагогічної системи, зокрема цілісного освітнього процесу пропонує М. Даудов. У цьому контексті під педагогічними умовами автор розуміє взаємодію сукупності заходів педагогічного процесу, що забезпечує формування правової компетентності майбутніх педагогів у процесі професійної підготовки (Даудов, 2017, с.61).

Поняття «педагогічні умови» Л. Ніколаєва визначає як сукупність об'єктивних можливостей змісту навчання, методів, організаційних форм і матеріальних можливостей його здійснення, що забезпечує успішність досягнення поставленого завдання (Ніколаєва, 2005, с.88).

Педагогічними умовами В. Майорський називає сукупність обставин, засобів, компонентів навчального процесу, за яких навчання учнів $\epsilon$ ефективним, а також обстановка й фактори, що на нього впливають (Майорський, 2016, с.61).

Отже, у науково-педагогічній літературі умови визначаються як сукупність заходів (об'єктивних можливостей) освітнього процесу, які забезпечують досягнення студентами вищого рівня діяльності.

Сутність педагогічних умов може бути представлена такими підходами: комплекс заходів, зміст, методи і форми виховання, що забезпечують організацію матеріально-просторового середовища; елемент педагогічної системи, що відображає можливості освітнього середовища та впливу на студентів (зміст, засоби, форми, технології).

Дотримуючись другої позиції, визначаємо педагогічні умови як сукупність організаційних форм, педагогічних взаємодій, змісту навчання (дисциплін), що здійснюють спрямований вплив на студентів у ході їх фахової підготовки.

Одним із завдань дослідження - визначення найбільш необхідних і достатніх педагогічних умов для формування правової культури майбутніх учителів історії та правознавства.

Отже, під необхідними педагогічними умовами розумітимемо ті, які забезпечують процес формування правової культури майбутніх учителів у ході фахової підготовки, а під достатніми - таке їх поєднання, яке забезпечує ефективність цього процесу. Ці умови, по-перше, повинні визначатися межами освітнього процесу, по-друге, вони повинні бути взаємопов'язані.

У ході визначення педагогічних умов формування правової культури майбутнього вчителя історії i правознавства у фаховій підготовці нами проаналізовано умови, запропоновані науковцями відповідно до тематики їх 
дослідження (А. Аникина (2011), С. Василина (2017), М. Даудов (2017), І. Срмакова (2011), О. Іваній (2013), В. Майорський (2016), О. Наливайко (2002), Н. Ржевська (2017), О. Сергійчук (2010), В. Ситянін (2010), М. Фабриков (2017), А. Шайдуров (2001), П. Шахбанова (2012)) та групи умов (Е. Болотова (2007), М. Даудов (2017), Л. Николаєва (2005), О. Соколова (2011)).

Здійснений аналіз засвідчив, що у педагогічній літературі існують різні думки щодо наявності педагогічних умов, що сприяють формуванню правових якостей фахівця. Їх різноманіття пояснюється відмінностями в постановці мети і задач конкретного дослідження, вимогами суспільства до підготовки студентів та іншими чинниками.

Мета статті - обгрунтувати педагогічні умови формування правової культури майбутніх учителів історії та правознавства у їх фаховій підготовці, розкрити шляхи їх реалізації.

Виклад основного матеріалу дослідження. На основі аналізу педагогічних умов, запропонованих науковцями, вважаємо необхідними і достатніми такі педагогічні умови формування правової культури майбутніх учителів історії та правознавства: стимулювання мотивації пізнавальної діяльності, ціннісного ставлення студентів до норм права з урахуванням сучасних суспільно-історичних реалій 3 використанням інноваційних форм i активних методів навчання; диверсифікація змісту навчальних дисциплін для формування у студентів позитивного ставлення до правових знань; використання освітніх технологій, що забезпечують реалізацію правового досвіду (педагогічна і правова практики, правовиховна діяльність, громадська активність).

Перша умова спрямована на дослідження мотиваційної сфери розвитку особистості, на формування стійких поглядів правомірної поведінки, нетерпимість до порушників законів, соціальних установок, які не суперечать вимогам юридичних норм, що узгоджуються 3 ними. 3 цією метою використано лекцію проблемного характеру, лекцію-візуалізацію, семінар-круглий стіл, семінардворядний круглий стіл, семінар-виставку, стендову доповідь, семінар-ділову гру, практичні заняття-тренінги, індивідуальний практикум, конкурси, вечори запитань і відповідей, тренінги, портфоліо, а в умовах педагогічної та правової практики зустрічі з представниками правоохоронних органів.

3 метою формування позитивної мотивації, ціннісного ставлення до правових норм, формування знань, умінь і навичок при організації і проведенні практичних робіт, навчальна діяльність студентів організовується (в груповій або індивідуальній формах) з використанням активних методів навчання: кейс-методу, дискусій, «акваріумних» дискусій, ігрових методик (ділові, рольові ігри, драматизація), мозкового штурму, методу правотворчості, кластерного аналізу тексту, оцінки подій тощо, що дозволяє у процесі виконання практичних завдань забезпечити занурення майбутнього вчителя історії та правознавства у штучно створене професійне середовище.

У ході семінарських занять 3 дисципліни «Теорія держави і права», на тему «Поняття держави», ми рекомендували студентам проаналізувати різні теорії про сутність держави (теорію еліт, технократичну, теорію плюралістичної демократії тощо), вибрати з усіх представлених теорій найбільш переконливу й обгрунтувати свій вибір. На семінарському занятті на тему «Норми права» зіставлялися різні підходи до структури правової норми (триелементна або двоелементна), i, враховуючи обрану позицію, здійснювався аналіз структури конкретної норми. Студентам пропонувалося також проаналізувати структуру однієї і тієї ж норми 3 різних точок зору. 
Активізації навчальної діяльності, вдосконаленню правових умінь і навичок, розвитку аналітичних здібностей при вивченні правових та історичних дисципліни сприяв семінар - круглий стіл «Права дитини». Для коротких повідомлень студентам були запропоновані такі питання: «Що таке життя?», «Коли починається життя 3 погляду наших законів?», «У чому полягає право дитини на життя?», «Як проявляється взаємозв'язок права на життя із зростанням озброєння, роззброєння, конверсією?»

Під час обговорення кожного питання увага акцентувалася на наявності означеної проблеми в нормативно-правових документах. У ході семінару розглядалися актуальні поняття «життя людини», «активна і пасивна евтаназії», «вбивство дитини», «трансплантація», «клонування», «суїцид».

Здійснювалася організація такої форми семінару, як «дворядний круглий стіл». У ході семінару обиралися дві групи, які висловлювали свої уявлення, думки, досвід з теми, що обговорювався. Учасники створили два півкола. Менше півколо (внутрішнє) складали студенти, які мали чітко сформовану думку з пропонованого питання або досвід реалізації рішень проблеми. Більше півколо (зовнішнє) утворлили інші учасники семінару.

У плані розвитку правових навичок майбутніх учителів історії і правознавства було запропоновано семінар-виставку. Під час вивчення навчальних дисциплін використовувалися дві форми проведення семінарів-виставок. В одному випадку студенти представляли свої розробки у вигляді планшетів, стінгазет, альбомів і брали участь в обговоренні результатів дослідження. В іншому - відвідали виставковий центр і ознайомилися 3 презентаціями освітніх закладів, взяли інтерв’ю у відвідувачів, організаторів виставок, представників закладів вищої освіти, потім на основі зібраних матеріалів провели тематичний «круглий стіл». Прикладом $\epsilon$ проведений семінар-виставка на тему «Платні послуги освітнього закладу». На занятті проводилося обговорення проблеми за напрямами: види освітніх закладів, що пропонують додаткові освітні послуги, їх організаційноправова форма; нормативно-правова база освітнього закладу при наданні зазначених послуг споживачеві; поняття і види освітньої послуги, їі нормативноправове оформлення; правові наслідки неякісного надання додаткових освітніх послуг.

Кожен студент, використовуючи рекламну продукцію, отриману в ході бесіди 3 представниками освітніх закладів, доповідав про результати проведеного дослідження.

Інший вид семінару-виставки «Стендова доповідь» проведено під час вивчення дисципліни «Методика навчання правознавства» на тему «Права дитини в сучасній Україні». Ця тема не вивчалася в аудиторний час, а була виконана студентами самостійно 3 використанням проєктної технології. Результатом досліджень студентів стали стендові доповіді про нормативно-правове забезпечення правового статусу різних категорій дітей.

У процесі формування правової культури майбутніх учителів історії i правознавства ефективним був семінар-ділова гра, організований у формі розробки i захисту студентами проєктів, групового вирішення означеної проблеми, командного виконання дослідницького завдання тощо. Як приклад, ділова гра на тему «Правовий статус учня».

Під час навчальних занять використовувалися вправи і практичні роботи, які проводилися після вивчення теми «Закономірності розвитку суспільства» (дисципліна «Історія держави i права України»), оскільки вона носить узагальнюючий характер і реалізується не тільки під час практичних занять 
аудиторного характеру, а й за межами навчального закладу (у формі самостійної роботи студента, під час проходження педагогічної практики у школі).

Однією з форм, яка поєднує самостійну аудиторну і позааудиторну роботу студентів, обрано індивідуальний практикум, який складається 3 двох частин: вирішення індивідуальних завдань - ситуацій правового характеру, адекватних реальному життю (аудиторна робота), і виконання спеціальних завдань, а саме: аналіз додаткової юридичної літератури, підготовка повідомлень, рефератів, доповідей 3 проблем правового виховання, робота 3 правовими довідковими системами, участь в конференціях, конкурсах (позааудиторна робота).

Ефективною формою роботи є портфоліо, яке складається 3 блоків, що характеризують свій аспект готовності до професійної діяльності з використанням правових знань. Перший блок «Навчальна і наукова діяльність» характеризує навчальну діяльність студента, оволодіння знаннями 3 метою поглибленого вивчення права тощо, другий - «Правовиховна діяльність» передбачає правове виховання учнів у школі, проведення просвітницьких заходів правової спрямованості для учнів і батьків; третій - «Професійна творчість» передбачає демонстрацію досвіду практичної творчої діяльності і включає реалізацію студентами проєкту «Програма правового виховання» у школах; четвертий «Участь у соціальному житті» враховує характер і рівень суспільної діяльності, роботу клубів, гуртків, занять спортом.

Найефективнішим методом формування практичної складової правової культури є тренінги, наприклад, «Я маю право». Учасники тренінгу діляться на малі групи, кожна група отримує однакове завдання: назвати по десять прав, які вони вважають найважливішими для людей. Кожна група зачитує права, ті, що повторюються, видаляються. Отже, виробляється загальний список 310 основних прав. Студенти включили в цей список право на життя, освіту, здоров'я, віросповідання, свободу слова, зібрань та ін.

У ході дослідницької діяльності нами розроблений і впроваджений в освітній процес комплекс тренінгів: 3 формування «Я-позиції», правової поведінки і професійно-правової комунікації.

Важливу роль у цьому процесі відіграє педагогічна практика, у програму якої включені додаткові завдання і внесені доповнення. У ході правової практики студенти отримують правову інформацію під час зустрічі 3 представниками правоохоронних органів та інших держструктур; організованих разом 3 ними «круглих столів», конференцій, семінарів з проблем, які пов'язані зі сферою права «Право на освіту: міф чи реальність?», «Права дитини в школі», «Проблеми правової соціалізації молоді», «Правові основи захисту сім’ї та дитинства»; та конкурсів на кращу студентську наукову доповідь «Права людини в сучасному світі», та проєкт заходу «Тиждень прав дитини в школі», присвячений Дню прав людини.

Ефективною формою правового виховання студентської молоді $є$ вечори запитань і відповідей на правові теми за участю юристів-практиків, усні юридичні журнали, конференції, диспути, вікторини.

Формуванню правової культури майбутніх вчителів історії та правознавства сприяли такі форми як присутність студентів на судових засіданнях, засіданнях комісій у справах неповнолітніх $\mathrm{i}$ захисту їх прав при районних держадміністраціях. Успішному застосуванню цих форм сприяє попереднє ознайомлення студентів із сутністю кримінальної або цивільної справи, а також із тими нормативними актами, які регулюють даний прецедент. 
Як відзначає М. Даудов, у практиці роботи зі студентами все частіше використовують інтерактивні методи навчання. Вони дозволяють активізувати навчальний процес, створити сприятливий емоційний фон, сприяють розвитку пізнавального інтересу до предмета, творчих здібностей учнів, навичок самостійної роботи, відносин дружби і взаємодопомоги в колективі. Для цього організовуються індивідуальні, парні та групові види роботи, дослідницькі проєкти, рольові та ділові ігри, робота з документами та різними джерелами інформації, творчі роботи та ін. (Даудов, 2017, с.77).

Серед активних методів ефективною $\epsilon$ тематична дискусія, яка використовувалась на різних заняттях: лекційних, семінарських, надаючи їм діалогової форми. Так, при вивченні теми «Цілі і завдання навчання історії у школі», студентам запропоновано низку практичних завдань: зіставити поняття «минуле», «історія», «історична наука», «історія як навчальний предмет», 3'ясувати, чи є серед них синоніми, та обгрунтувати свій вибір.

У процесі викладання історичних i правових дисципліни застосовано «акваріумну» дискусію, як особливий варіант організації колективної взаємодії при роботі 3 навчальним правовим матеріалом, зміст якого пов'язаний із суперечливими підходами, конфліктами, розбіжностями.

В основі навчальних ігор - ігрові моделі, що включають конкретні їх форми (імітаційні, ділові тощо), які стають або елементом конкретного заняття, або його формою (наприклад, заняття - гра «Судове засідання»).

На практичних заняттях проводилися ділові ігри на тему: «Профспілка і захист прав працівника», «Система домовленостей».

Ефективною є драматизація як засіб виховання особистості як суб'єкта власного життя шляхом ситуації вибору в ході гри, учасником, глядачем або автором яких $\epsilon$ студент. У той же час в процесі позааудиторної роботи з історії використовуються, хоча і не часто, інсценівки, спектаклі на історико-правові теми. Мова йде не про постановку спектаклю в цілому, драматизація може зайняти лише декілька хвилин. Варіантом стала розроблена гра з елементом драматизації «Гайдпарк», яку проведено під час лабораторних занять. Студентам запропоновано спробувати себе в ролі ораторів і виступити 3 короткими промовами про демократію (регламент встановлено)

На відміну від ділової гри, у рольовій аналізуються не тільки змістові, але й соціально-психологічні проблеми, основний наголос робиться на розвиток індивідуальних особистих якостях учасника гри. В основі сюжетно-рольових ігор може лежати будь-яка життєва ситуація (вигаданий або реальний сюжет), що носить правовий характер. У процесі викладання дисципліни «Методика навчання правознавства» застосовано ігри: «Споживач, захисти свої права» на тему «Закон про захист прав споживача»; «Острів» та «Добра фея» на тему «Права людини і дитини»; «Продаж телевізора» на тему «Громадянське право»; «Прийом у адвоката»; використання правил і принципів телевізійної гри «Що? Де? Коли?».

Одним із ефективних методів у формуванні правової культури $є$ «мозковий штурм». Метод заздалегідь планувався як фрагмент заняття або як заняття в цілому. Наприклад, під час заняття «Теорія держави і права» метод «мозкового штурму» застосовувався при вивченні теми «Механізм (апарат) держави», коли йшлося про шляхи вдосконалення діяльності механізму держави; теми «Правова держава» - під час обговорення труднощів іiі формування в Україні; теми «Законність, правопорядок, суспільний порядок», де аналізувалися напрями зміцнення законності і правопорядку в країні, а також тем «Правомірна поведінка i 
правопорушення», «Юридична відповідальність», у яких розглядалися способи зниження рівня злочинності та правопорушень, їх профілактика.

Особливе місце займав метод аналізу конкретних проблемних ситуацій правового характеру (кейс-метод), суть якого полягала в тому, що викладач штучно створював у навчальному процесі проблемні ситуації, запозичені з професійної практики. Найбільшу ефективність проблемна ситуація мала на семінарських заняттях з дисципліни «Історія держави і права України».

Усвідомленому ставленню студентів до актуальності правових проблем у майбутній професійній діяльності сприяли практичні заняття з використанням прийому «круглий стіл». Наприклад, розглядаючи педагогічний етюд «Крадіжка», студенти давали правову й моральну оцінку дев'ятикласнику, який вчинив правопорушення.

Організації активної правової діяльності студентів за допомогою спільного або самостійного складання правових документів (договору, позовної заяви, клопотання та ін.) сприяло застосування методу правотворчості. Цей метод формував у студентів стійке ставлення до правового статусу свого оточення, оскільки створені у процесі творчості норми, правила тощо, часто не узгоджуються 3 існуючими реаліями або модельованими ситуаціями, і ця невідповідність, неврегульованість змушувала студента включатися в активний процес подолання розбіжностей між практикою і виробленою з його участю документацією.

Особливий інтерес викликає у студентів методика роботи із правовими документами. Наприклад, при розгляді теми «Основи трудового права», студенти практикувалися у складанні заяви про прийом на роботу з дотриманням реквізиту такого документа; у процесі вивчення теми «Право на освіту» працювали над аналізом вилучення із Закону України «Про освіту» тексту про права, обов’язки та відповідальність у сфері освіти батьків (законних представників) неповнолітніх дітей.

Отже, формування правової культури майбутніх учителів історії i правознавства, яке здійснювалося в ході реалізації педагогічних умов, визначається комплексним застосуванням інноваційних форм та активних методів навчання.

Друга педагогічна умова передбачала вивчення студентами навчальних дисциплін: «Теорія держави і права», «Історія держави і права України», «Теорія і методика навчання історії», «Методика навчання правознавства». Основною метою обрано практико-орієнтовану фахову підготовку майбутніх педагогів (система правових знань, умінь, навичок та ціннісних орієнтацій, правових установок, що регулюють поведінку особистості в різних ситуаціях). На заняттях 3 «Теорії і методики навчання історії» студенти розглядали поняття освітніх програм, базисного плану і навчальних програм дисциплін. Для цього використано метод аналізу нормативних актів освітнього закладу, що дозволяє познайомитися 3 реалізованими в конкретних школах навчальними планами, усвідомити їх структуру, призначення, різноманіття реалізації освітніх програм одного рівня.

На семінарських заняттях використовувався метод юридичного висновку, суть якого полягає в тому, що при вирішенні історичних питань студенти роблять висновок про поведінку учнів і педагогів з правових позицій.

Зміст дисципліни «Теорія держави і права» організовано у вигляді послідовних блоків навчальної інформації: «Основи теорії держави і права», «Основи галузевого законодавства», «Правове регулювання професійної діяльності».

У межах першого блоку студенти оволодівали теоретичними знаннями про систему права, правові норми і правовідносини, суб'єкти права і способи реалізації ними правових норм, джерела права, правопорушення i юридичну 
відповідальність. При вивченні питань 3 теорії права увага зверталася на освітнє право, його джерела, особливості освітніх правовідносин за об'єктом, суб'єктом і змістом. При вивченні основ галузевого законодавства розглянуті норми, які пов'язані з майбутньою професійною діяльністю студентів.

При розгляді нормативної бази діяльності освітнього закладу використовували метод «розбору ділової документації». Студенти на основі аналізу локальних актів освітнього закладу визначали громадські органи управління, способи їх формування та обсяг повноважень; аналізували статути різних типів освітніх закладів, співвідносили їх, знаходили в них норми, що суперечать закону «Про освіту»; виявляли сукупність локальних актів, які визначають правовий статус учнів.

Під час вивчення курсу «Методика навчання правознавства» студенти вирішували професійно-орієнтовані правові завдання у ході дидактичної гри «Права дитини».

Професійно-орієнтований зміст курсу «Теорія держави і права» визначив предметний зміст правових завдань: правоорієнтаційних, правооцінних i правореалізаційних. Правоорієнтаційні завдання спроєктовані за темами: «Право в системі соціального регулювання», «Джерела права», «Система права», «Правовідносини». Вирішення завдань цього типу відбувається на семінарах у процесі дидактичного тренінгу.Для включення правооцінних завдань в освітній процес використовувався метод аналізу конкретних ситуацій. До уваги студентів пропонувалася правова ситуація, яка пов'язана з уже сформованою подією i вимагала правової оцінки.

Під час вивчення основ правового регулювання професійної діяльності студенти вирішували завдання. До уваги майбутніх педагогів пропонувалися ситуації-питання, що вимагають або моделювання варіанту поведінки в умовах, що склалися, або вказівки на те, що зроблено неправильно.

Вирішення задач в освітньому процесі здійснювалося з використанням методу «юридична консультація». Студенти виступали в ролі «юристів» і відповідали на запитання, що передбачали звернення до нормативних актів. Тому студенти працювали в групах, а потім колективно обговорювали ці відповіді.

Під час вивчення дисциплін «Теорія і методика навчання історії», «Методика навчання правознавства» застосовано метод «графіті». Студенти на невеликих аркушах паперу (0,5 сторінки) фломастерами, кольоровою крейдою, олівцями формулювали відповіді на поставлені завдання, наприклад: «Продовжити визначення: «Формування правової культури у ході вивчення історії (правознавства) здійснюється...».

Значну роль у процесі формування правової культури студентів відіграє, на нашу думку, розширення кола дисциплін і курсів, що вивчаються за вибором студента. Тому нами розроблені такі спецсемінари: «Правова культура майбутнього вчителя історії і правознавства», «Основи правовиховної роботи у школі», «Створення, оновлення та захист інформації відповідно до змін у законодавстві», рефлексивний спецсемінар.

Третя педагогічна умова передбачала упровадження таких технологій: проєктного навчання, проблемного навчання, організації самостійної роботи студентів, активного навчання «Кластери», інформаційно-комунікаційних.

Більш детально розглянемо технологію активного навчання «Кластери». Порядок застосування технології грунтувався на темі «Юридична відповідальність педагогічного працівника». До найбільш важливих понять віднесені такі: юридична відповідальність, обов'язок, повага прав і свобод, юридичні факти і 
події, види юридичної відповідальності, правомірна поведінка, правопорушення, злочин, склад проступку педагогічного працівника, форми провини.

Під час проведення заняття 3 використанням цієї технології застосовано покроковий алгоритм.

Крок 1. Студентам пропонується у центрі чистого аркуша записати словосполучення «Юридична відповідальність».

Крок 2. Студенти мають на всій поверхні листа у довільній формі розмістити терміни, які відповідають розкриттю сутності даного поняття.

Крок 3. Між написаними на аркуші термінами стрілками вказується зв'язок. Стрілка повинна відповідати ходу розкриття змісту кожного наступного терміну (поняття). На аркуші виходить зображення «кластера студента».

Крок 5. На дошці (екрані) подається словосполучення «Юридична відповідальність» і пропонується запитання «Що означає це поняття?». Даний крок - це початок формування «кластера студента».

Крок 6. Кожен студент «ланцюжком» відповідає на це запитання. Допускається будь-яка форма відповіді.

Крок 7. Студентам пропонується знайти словосполучення у словнику і зачитати його зміст. Фіксується збіг змісту поняття, знайденого у словнику, із висловленими формулюваннями студентів.

Крок 8. На зворотному боці того ж листа студенти записують перше словосполучення і його визначення, сформульоване ними самостійно і уточнене за допомогою словника.

Крок 9. Пропонуються такі запитання: «Коли настає відповідальність фахівця?», «Що є підставою для виникнення юридичної відповідальності педагога?».

Крок 10. Студенти пропонують різні варіанти відповіді. Для підведення студентів до необхідної відповіді наводиться приклад з педагогічної практики.

Крок 11. Студенти у ході обговорення 3'ясовують, що моментом настання юридичної відповідальності фахівця є юридичний факт, юридична подія.

Крок 12. На дошці (екрані) розміщують два поняття: «юридичний факт», «юридична подія», які взаємопов'язані з поняттям «юридична відповідальність». Студенти перевіряють наявність запису зазначених словосполучень у своїх листах. У разі відсутності цих понять у кластері, студенти доповнюють свою схему необхідними термінами.

Крок 13. Студентам пропонується сформулювати визначення нових термінів. Допускається фронтальне та індивідуальне опитування, пошук змісту терміна за словником. Після того як буде сформульована конструкція визначення необхідного терміну, його зміст записується студентами на зворотному боці аркуша.

Крок 14. Розглядаючи зміст кожного терміна, уточнюючи його визначення, поступово відкриваються на дошці (екрані) заздалегідь заготовлені зображення логічної схеми змісту основного поняття (кластер студента), яка обговорюється із подальшим аналізом кожного поняття у зіставленні 3 поняттям «юридична відповідальність».

Висновки і перспективи подальших розвідок. Обгрунтовано педагогічні умови формування правової культури майбутніх учителів історії та правознавства у фаховій підготовці: 1) стимулювання мотивації пізнавальної діяльності, ціннісного ставлення студентів до норм права з урахуванням сучасних суспільно-історичних реалій $з$ використанням інноваційних форм і активних методів навчання; 2) диверсифікація змісту навчальних дисциплін для формування у студентів позитивного ставлення до правових знань; 3) використання освітніх технологій, що 
забезпечують реалізацію правового досвіду (педагогічна і правова практики, правовиховна діяльність, громадська активність).

Реалізація першої умови здійснювалась під час лекції проблемного характеру, лекції-візуалізації, лекції-прес-конференції, семінарі-круглому столі, семінарідворядному круглому столі, семінарі-виставці, стендовій доповіді, семінарі-діловій грі, практичних заняттях-тренінгах, індивідуальному практикумі, конкурсах, вечорах питань і відповідей, тренінгах, портфоліо, а в умовах педагогічної та правової практики - під час зустрічей з представниками правоохоронних органів.

Застосовано активні методи навчання: кейс-метод, дискусія, «акваріумна» дискусія, ігрові методики (ділові, рольові ігри, драматизація), мозковий штурм, метод правотворчості, кластерний аналіз тексту, оцінка подій тощо.

Друга умова передбачала вивчення студентами навчальних дисциплін «Теорія держави і права», «Історія держави і права України», «Теорія і методика навчання історії», «Методика навчання правознавства» та спецсемінарів «Правова культура майбутнього вчителя історії і правознавства», «Основи правовиховної роботи в школі», «Створення, оновлення та захист інформації відповідно до змін у законодавстві», рефлексивний спецсемінар. Основною метою обрано практикоорієнтовану фахову підготовку майбутніх педагогів (система правових знань, умінь, навичок та ціннісних орієнтацій, правових установок, що регулюють поведінку особистості в різних ситуаціях).

Третя умова передбачала упровадження технологій проєктного навчання, проблемного навчання, організації самостійної роботи студентів, активного навчання «Кластери», інформаційно-комунікаційних.

Перспективу подальших досліджень вбачаємо в експериментальній перевірці запропонованих педагогічних умов формування правової культури майбутніх учителів історії та правознавства у їх фаховій підготовці.

\section{СПИСОК ВИКОРИСТАНИХ ДЖЕРЕЛ}

Николаева, Л. (2005). Формирование правовой культуры студентов. Кандидат педагогических наук.

Шахбанова, П. (2012). Организачионно-педагогические условия формирования коммуникативной культуры будущего учителя права. Кандидат педагогических наук.

Даудов, М. (2017). Формирование правовой компетентности студентов педагогического вуза. Кандидат педагогических наук.

Шайдуров, А. (2001). Педагогические условия развития правовой культурь будущих учителей. Кандидат педагогических наук.

Майорський, В. (2016). Методика навчання конституційного права учнів профільних класів. Кандидат педагогических наук.

Аникина, А. (2011). Формирование правовой компетентности будущего педагога с использованием комплекса профессионально-ориентированных правовых задач. Кандидат педагогических наук.

Василина, С. (2017). Психолого-педагогічні умови правової підготовки учнів професійно-технічних навчальних закладів. Кандидат педагогічних наук.

Єрмакова, I. (2011). Модель підготовки майбутнього вчителя суспільствознавчих дисциплін до використання дослідницької технології у професійній діяльності. Наукові праці Чорноморського державного університету імені Петра Могили комплексу «Києво-Могилянська академія», 173 (161). с. 32-37.

Іваній О. (2013). Формування правової компетентності майбутніх учителів у процесі професійної підготовки. Проблеми підготовки сучасного вчителя. 7. 
c. $162-167$.

Наливайко, О. (2002). Теоретико-правові проблеми захисту прав людини. Кандидат юридичних наук

Ржевська, Н. (2017). Формування правової компетентності майбутніх бакалаврів з товарознавства $i$ торговельного підприємництва у процесі професійної підготовки. Кандидат педагогічних наук.

Сергійчук, О. та Демуз, І. (2010). Професійна педагогічна готовність учителя історії в умовах модернізації вищої освіти. Вісник Житомирського державного університету, 50, с. 125-129.

Ситянін, В. (2010). Формування правової компетентності науковопедагогічних працівників вищцої школи. Кандидат педагогічних наук.

Фабриков ,М. (2017). Педагогические условия воспитания правовой культуры старшеклассников: монография. Владимир: Изд-во ВлГУ, 2017. 159 с.

Болотова, Е. (2007). Система непрерывной правовой подготовки педагогических кадров. Доктор педагогических наук

Соколова, О. (2011). Формирование гражданственности и правовой культурь студентов в образовательном процессе вузов сочиикультурной сферы. Кандидат педагогических наук.

\section{REFERENCES}

Nykolaeva, L. (2005). Formyrovanye pravovoi kulturbl studentov. [Formation of law culture of students.] Kandydat pedahohycheskykh nauk. (in Russian).

Shakhbanova, P. (2012). Orhanyzatsyonno-pedahohycheskye uslovyia formyrovanyia kommunykatyvnoi kulturb budushcheho uchytelia prava. [Organizational and pedagogical conditions for the formation of a communicative culture of the future teacher of law] Kandydat pedahohycheskykh nauk. (in Russian).

Daudov, M. (2017). Formyrovanye pravovoi kompetentnosty studentov pedahohycheskoho vuza. [Formation of the law competence of students of a pedagogical university] Kandydat pedahohycheskykh nauk. (in Russian).

Shaidurov, A. (2001). Pedahohycheskye uslovyia razvytyia pravovoi kulturbl budushchykh uchytelei. [Pedagogical conditions for the development of the law culture of future teachers.] Kandydat pedahohycheskykh nauk. (in Russian).

Maiorskyi, V. (2016). Metodyka navchannia konstytutsiinoho prava uchniv profilnykh klasiv. [Methods of teaching the constitutional law of students of specialized classes.]. Kandydat pedahohichnykh nauk. (in Ukrainian).

Anykyna, A. (2011). Formyrovanye pravovoi kompetentnosty budushcheho pedahoha s yspolzovanyem kompleksa professyonalno-oryentyrovannblkh pravovblkh zadach. [Formation of the law competence of the future teacher using a set of professionally-oriented law tasks] Kandydat pedahohycheskykh nauk. (in Russian).

Vasylyna, S. (2017). Psykholoho-pedahohichni umovy pravovoi pidhotovky uchniv profesiino-tekhnichnykh navchalnykh zakladiv. [Psychological and pedagogical conditions of law training of students of vocational schools] Kandydat pedahohichnykh nauk. (in Russian).

Yermakova, I. (2011). Model pidhotovky maibutnoho vchytelia suspilstvoznavchykh dystsyplin do vykorystannia doslidnytskoi tekhnolohii u profesiinii diialnosti. [Model of preparation of the future teacher of social sciences for use of research technology in professional activity]. Naukovi pratsi Chornomorskoho derzhavnoho universytetu imeni Petra Mohyly kompleksu «Kyievo-Mohylianska akademiia», 173 (161). s. 32-37. (in Ukrainian).

Ivanii O. (2013). Formuvannia pravovoi kompetentnosti maibutnikh uchyteliv u 
protsesi profesiinoi pidhotovky. [Formation of law competence of future teachers in the process of professional training] Problemy pidhotovky suchasnoho vchytelia. 7. s. 162167. (in Ukrainian).

Nalyvaiko, O. (2002). Teoretyko-pravovi problemy zakhystu prav liudyny. [Theoretical and law problems of human rights protection] Kandydat yurydychnykh nauk. (in Ukrainian).

Rzhevska, N. (2017). Formuvannia pravovoi kompetentnosti maibutnikh bakalavriv $z$ tovaroznavstva $i$ torhovelnoho pidpryiemnytstva u protsesi profesiinoi pidhotovky. [Formation of law competence of future bachelors in commodity science and trade entrepreneurship in the process of professional training] Kandydat pedahohichnykh nauk.(in Ukrainian).

Serhiichuk, O. ta Demuz, I. (2010). Profesiina pedahohichna hotovnist uchytelia istorii v umovakh modernizatsii vyshchoi osvity. [Professional pedagogical readiness of a history teacher in the conditions of modernization of higher education] Visnyk Zhytomyrskoho derzhavnoho universytetu, 50, s. 125-129. (in Ukrainian).

Sytianin, V. (2010). Formuvannia pravovoi kompetentnosti naukovopedahohichnykh pratsivnykiv vyshchoi shkoly. [Formation of law competence of scientific and pedagogical workers of higher school] Kandydat pedahohichnykh nauk. (in Ukrainian)

Fabrykov ,M. (2017). Pedahohycheskye uslovyia vospytanyia pravovoi kulturbl starsheklassnykov: monohrafyia. [Pedagogical conditions of education of law culture of senior pupils] Vladymyr : Yzd-vo VlHU, 2017. 159 s. (in Russian).

Bolotova, E. (2007). Systema neprerblvnoi pravovoi podhotovky pedahohycheskykh kadrov. [The system of continuous law training of teachers] Doktor pedahohycheskykh nauk. (in Russian).

Sokolova, O. (2011). Formyrovanye hrazhdanstvennosty y pravovoi kulturbl studentov $v$ obrazovatelnom protsesse vuzov sotsyokulturnoi sferbl. [The formation of citizenship and law culture of students in the educational process of universities in the socio-cultural sphere] Kandydat pedahohycheskykh nauk. (in Russian).

\title{
PEDAGOGICAL CONDITIONS OF FORMATION OF LEGAL CULTURE OF FUTURE TEACHERS OF HISTORY AND LEGAL EDUCATION IN PROFESSIONAL TRAINING
}

\author{
Daria Koval \\ Postgraduate, Pavlo Tychyna \\ Uman State Pedagogical University, \\ Uman, Ukraine, \\ ORCID: 0000-0003-0765-7649 \\ e-mail: akoval85@gmail.com
}

\begin{abstract}
The pedagogical conditions of formation of legal culture of future teachers of history and jurisprudence in professional preparation are substantiated in the article: stimulation of motivation of cognitive activity, value attitude of students to norms of law taking into account modern socio-historical realities with use of innovative forms and active methods of teaching; diversification of the content of academic disciplines for students to develop a positive attitude to legal knowledge; the use of educational technologies that provide the implementation of legal experience (pedagogical and legal practices, law-enforcement activities, public activity).
\end{abstract}


The process of realization of the first condition, which was carried out at lectures of problematic nature, lectures-visualization, lectures-press-conferences, seminars - round table, seminars - double-row round table, seminar-exhibition, poster presentation, seminars-business game, practical classes, individual workshops, competitions, Q\&A nights, trainings, portfolios, and in pedagogical and legal practice, meetings with law enforcement officials. Active teaching methods have been applied: case method, discussion, aquarium discussion, game techniques (business, role play, dramatization), brainstorming, lawmaking, text analysis cluster, event evaluation, etc.

It was established that the second condition provided for the students to study the subjects of "Theory of State and Law", "History of State and Law of Ukraine", "Theory and methodology of teaching history", "Methods of teaching law" and special seminars "Legal culture of the future teacher of history and law", "Fundamentals of Law Enforcement at School," Creating, Updating and Protecting Information According to Changes in Legislation ", Reflective Special Seminar. The main purpose is to select practically oriented professional training of future teachers (system of legal knowledge, skills, values and orientations, legal frameworks that regulate personality behavior in different situations).

It is envisaged that the third condition was implemented with the help of the following technologies: project training, problem training, organization of students' independent work, active training "Clusters", information and communication.

We see the prospect of further research in the experimental verification of the proposed pedagogical conditions for the formation of the legal culture of future teachers of history and law in professional training.

Keywords: pedagogical conditions, formation of legal culture, future teachers of history and jurisprudence, norms of law, professional training, law-enforcement activity.

Стаття надійшла до редакиії 06. 05. 2020 р. 